Part 4.

Studia Iuridica Lublinensia vol. XXVII, 1, 2018

DOI: 10.17951/sil.2018.27.1.157

\author{
Antonio-Luis Martínez Pujalte \\ Miguel Hernández University, Elche, Spain \\ almart@umh.es
}

\title{
Spanish Legal System: Between Statutory Legal Systems and Case Law
}

\author{
Hiszpański system prawny - między systemami prawa stanowionego \\ a prawem precedensu
}

\section{SUMMARY}

The purpose of this article is to show that Spanish law is a paradigmatic example of the approach between traditional continental and Anglo-Saxon models of legal application. Two main factors have caused a deep transformation of Spanish legal system in the last decades: the position of Constitutional Court and its active role in legal creation, and the doctrine, which has been developed precisely by the Constitutional Court, on equality principle in the application of law. These changes show that the rigid traditional distinction among civil law and common law systems cannot be kept any more.

Keywords: Spanish legal system; statutory legal systems; case law

\section{INTRODUCTION}

The purpose of this article is to show that Spanish law is a paradigmatic example, among others, of the approach between traditional continental and Anglo-Saxon models of legal application. In other words, I am persuaded that the rigid traditional distinction among statutory legal orders, or legal orders based upon the centrality of statutory law as main legal source, and what could be called judicial legal orders, in which the kernel of law lies rather in the binding force of precedents and in the decisions of courts - in short, among civil law and common law systems - cannot be kept any more. And, in the case of Spain, this distinction, and the classification of our legal order as a statutory legal order, have collapsed due to two reasons that I will try to explain in the following paragraphs: in the first place, the position of the Constitutional Court; and, in the second place, the doctrine, which has been developed precisely by the Constitutional Court, on equality principle in the application of law. 


\section{THE POSITION OF CONSTITUTIONAL COURT IN SPANISH LEGAL SYSTEM}

As it is well known, the fact that most countries of continental Europe have an organ called "Constitutional Court" is due to the design made by H. Kelsen for the Austrian Constitution of $1920^{1}$. In North American mechanism of judicial review, judges are entitled to decide not to apply statutes which are opposed to the Constitution; in Europe, on the contrary, influence of legal positivism - one of the main thesis of which is the identification between legal order and statutory legislation - made it impossible to accept that a judge could decide not to apply a statute, and therefore Kelsen created another mechanism of constitutional jurisdiction. In Kelsen's proposal courts have the duty to apply statutes, not the Constitution; but, to assure supremacy of the Constitution, a specific organ is created, which has the capacity to certify that statutes comply with the Constitution and to expel from the system those who do not. We have thus an institution which is specialized in the control of constitutionality of laws. In this model, Constitutional Court, despite its name, is not properly a court, a judicial body; it does not judge, and therefore it is placed apart from the structure of the Judiciary. It is rather a legislative organ, but a negative legislator, which expels from legal order, which annuls, laws that are contrary to the Constitution: "The decision of the Constitutional Court by which a statute was annulled had the same character as a statute which abrogated another statute. It was a negative act of legislation" 2 . That leads to a model of abstract and concentrated constitutional jurisdiction. Abstract because constitutionality of laws is assessed in abstract, independently from the cases to which such laws should be applied, and concentrated because it is entrusted to a single organ, which is Constitutional Court.

However, both constitutional conformation and practical development of European model of constitutional jurisdiction have made it clearly diverge from original Kelsen's design. Constitutional courts have indeed assumed a role that goes very much beyond the function of negative legislator assigned by Kelsen. And this appears quite evidently, in particular in the case of Spain, in three fundamental aspects.

In one hand, there is a procedure, which is called in Spanish recurso de amparo (constitutional complaint), through which every individual can denounce before the Constitutional Court a violation of one of his or her fundamental rights protected by the Constitution, provided that all previous judicial remedies have been exhausted $^{3}$; that means that, in a field of particular significance as the protection of

\footnotetext{
${ }^{1}$ On this question, S. Lagi, Hans Kelsen and the Austrian Constitutional Court (1918-1929), "Co-herencia" 2012, Vol. 9, pp. 273-295.

${ }^{2}$ H. Kelsen, Judicial Review of Legislation: A Comparative Study of the Austrian and the American Constitution, "The Journal of Politics" 1942, Vol. 4, DOI: https://doi.org/10.2307/2125770, p. 187.

${ }^{3}$ Not all Constitutional Courts have the capacity to examine constitutional complaints as explained in the text. For example, these do not exist in Italy or Poland, while they have experienced
} 
fundamental rights, the Constitutional Court can judge specific problems and assess the application of the Constitution regarding specific conflicts, which of course turns the Constitutional Court into a judicial body, which decides quid iuris?, what is law, in a particular dispute. Dealing with constitutional complaints, constitutional jurisdiction is no more abstract; on the contrary, it has an unlimited capacity to solve particular conflicts among individuals - provided that the violation of a fundamental right recognized by the Constitution has been invoked - acting thus as every other judicial body. The Statute of the Spanish Constitutional Court (Section 41) tried to restrict this capacity, limiting constitutional complaint to violations of fundamental rights caused by public powers; but even this clause was extensively interpreted from the very beginning, understanding that, when a judicial body fails to give adequate protection to a fundamental right that has been injured by an individual, it is the judicial body, and therefore a public power, who violates the right, and in this way constitutional complaint is opened to injuries or violations of fundamental rights caused by individuals against other individuals, in other words, to conflicts among private citizens.

A second important feature of our Constitutional Court is its definition, by Article 1 of its Statute, as the supreme interpreter of the Constitution. In the exercise of this function, the Court fixes the way in which the constitutional regulations have to be understood, and even discovers implicit constitutional contents. I will give two examples of implicit constitutional contents that have been formulated by the Spanish Constitutional Court. One of them is the determination of public interest as an essential requirement for the legitimate exercise of the right to freedom of information. Article 20 of the Spanish Constitution recognizes the right to communicate freely truthful information. However, throughout its case-law Constitutional Court has affirmed that legitimate exercise of freedom of information requires two conditions, truthfulness and public interest. The first one is explicitly mentioned by Constitution, but the second one is not; it has been deducted by Constitutional Court based on a teleological interpretation of the right to freedom of information, according to which the aim of this right is to contribute to free development of public opinion, and public opinion is only developed by news of public interest ${ }^{4}$. A requisite for the legitimate exercise of freedom of information has thus been introduced, which the Constitution does not establish explicitly, but which has the same relevance as the one that the Constitution does establish explicitly. A second example is a fundamental right that has been recognized by Constitutional Court

\footnotetext{
an extraordinary development in Germany or Spain. A quite complete comparative overview in Council of Europe, European Commission for Democracy through Law (Venice Commission), Study on Individual Access to Constitutional Justice, December 18, 2010.

${ }^{4}$ On this question, T. Domingo, ¿Conflictos entre derechos fundamentales? Un análisis desde las relaciones entre los derechos a la libre información y expresión y los derechos al honor y la intimidad, Madrid 2001, pp. 185-201.
} 
which is not specifically declared by the Constitution. And this is particularly relevant if we take into account that the Declaration of Rights of the Spanish Constitution is numerus clausus, in other words, unlike other constitutions which have opening clauses (e.g., Article 33 of the Argentinian Constitution), in ours there is no regulation that explicitly allows to recognize other fundamental rights different from those which are specifically enumerated. However, Article $18 \S 4$ of the Spanish Constitution states that "Law will limit the use of informatics" to protect rights to honor and privacy, and, based on this disposition, Constitutional Court has created a new fundamental right with substantive autonomy, which is the right to protection of personal data ${ }^{5}$.

But Constitutional Court does not only add contents to the Constitution, it also adds contents to statutory law. This is the third aspect I wanted to mention. According to the principle of conservation of statutes, which means that validity of statutes must be saved as long as there is any chance of interpreting them complying to the Constitution, Constitutional Court often adds contents to statutes to save its constitutionality. As A.R. Brewer-Carías has pointed out after a study of comparative law,

This role of Constitutional Courts has resulted from the surpassing of the classical binomial: unconstitutionality/invalidity-nullity that conformed the initial activity of Constitutional Courts as Negative Legislators, having Constitutional Courts, on the contrary, progressively assumed a more active role interpreting the Constitution, and the statutes in order not only to annul or not to apply them when unconstitutional, but to preserve the Legislator actions and the statutes it has enacted, interpreting them in harmony with the Constitution; molding these Constitutional Courts as important constitutional institutions in order to assist and cooperate with the legislator in its legislative functions ${ }^{6}$.

This function of Constitutional Court is performed mainly in the so-called "additive decisions". These respond to those cases in which "a legal disposition is censured not because of what it prescribes, but in so far as it fails to prescribe something" We can find a good example in the Decision of the Spanish Con-

5 The Spanish Constitutional Court initiated this way of reasoning in its Decision 254/1993 (July 20 ), in which it said that "our Constitution has incorporated a new constitutional guarantee, as a way to answer to a new form of specific threat to dignity and rights of the person [...]. In the present case we see an institution to guarantee other rights, mainly honour and privacy, but also an institution which is in itself a fundamental right or liberty, the right to liberty against potential attacks to the liberty and dignity of the person originated from an illegitimate use of the mechanized treatment of data" (Legal Fundament No. 6). But a complete development of this new right is provided mainly by Decision $292 / 2000$ (November 30), in which it is finally denominated "right to protection of personal data".

${ }^{6}$ A.R. Brewer-Carías, Constitutional Courts as Positive Legislators, [in:] General Reports of the XVIII ${ }^{\text {th }}$ Congress of the International Academy of Comparative Law, eds. K. Brown, D. Snyder, Dordrecht 2012, DOI: https://doi.org/10.1007/978-94-007-2354-2_23, p. 556.

7 A. Cerri, Corso di Gustizia Costituzionale, Milan 2001, p. 235. Italian Constitutional Court has made an intense use of these "additive decisions". See: ibidem, pp. 235-241. 
stitutional Court 134/1996 (July 22): it judges a statute which establishes a tax exemption for the pensions of workers with permanent disabilities integrated in Social Security system, but fails to provide the same exemption for public servants (who in Spain are not integrated in Social Security, but have a different system of social welfare). The Court appreciates that this difference of treatment between private and public employees violates equality principle declared by Article 14 of the Spanish Constitution. However, it does not annul the legal disposition as a whole, but only in so far as it excludes from the tax exemption civil servants with permanent disabilities. In other words, Constitutional Court extends the scope of the application of the statute; it adds to it a new content, which was not included in its original text (that is why decisions of this kind are called "additive decisions"). That means that Constitutional Court performs a law-making function; it is not a negative, but rather a positive legislator.

Of course, the observation of the wide activity and range of functions of Constitutional Court poses us, above all, the question of its legal and constitutional nature. What are exactly Constitutional Courts? It seems clear that Kelsen's definition of Constitutional Courts as negative legislators cannot be accepted anymore; but, what is the alternative? In the limits of this paper, it is not possible to enter in depth in this issue ${ }^{8}$, but I would suggest that the position of Constitutional Court in legal order has to be explained mainly in connection with its function as supreme interpreter of the Constitution. Constitutional Court is the institution with the duty of watching over the fulfillment of the Constitution, which is the supreme norm of legal order and the norm that establishes the basic values and principles which provide the essential structure of political coexistence of the community. The Court performs this role carrying out a function of jurisdictional nature, which allows to call it a judicial body, and more exactly the supreme judicial organ - because it is the supreme interpreter of the supreme norm of legal order - clearly said, it is the summit of Judicial Branch ${ }^{9}$. As summit of one of the three branches of Government, it is an institution of government, that together with Executive and Legislative participates in the political direction of the State, in other words, in the role of adopting

${ }^{8}$ On this question, E. Aja, M. González Beilfuss, Conclusiones generales, [in:] Las tensiones entre el Tribunal Constitucional y el legislador en la Europa actual, Barcelona 1998, pp. 258-291.

${ }^{9}$ In most countries with a Constitutional Court, there is also a judicial organ called Supreme Court, which is often defined as the summit of the Judiciary. This is due to Kelsen's influence, because, as it has been said, he placed Constitutional Court apart from the Judiciary. But my opinion is that, despite the denominations, the real Supreme Court is Constitutional Court. Article 123.1 of Spanish Constitution supports indirectly this thesis, because it says that the Supreme Court "is the highest judicial body in all branches of justice, except with regard to Constitutional guarantees". That means that, when constitutional matters - which are the most important matters - are involved, the Supreme Court is no more the highest judicial body: it is the highest judicial body only when no constitutional issues - e.g., fundamental rights protected by the Constitution - enter into the debate. 
basic decisions on social coexistence; the only difference with other institutions of government being that decisions of the Constitutional Court cannot be based on discretionary reasons or reasons of opportunity, but only on the fulfillment of constitutional directives. But, due to its nature of supreme interpreter of the Constitution and summit of the Judiciary, decisions of the Constitutional Court are endowed with a singular authority (in Spanish legal system, this authority is shown, e.g., by the rule contained in Section 5 of Spanish Judiciary Act, which indicates that all judicial bodies must follow the interpretation of the Constitution resulting from the decisions adopted by Constitutional Court in any kind of procedures).

What has been argued so far shows, without doubt, the breakdown of legalistic model. In Spanish legal order, in fact, supremacy does not belong to statutory laws any more. Supremacy belongs to a judicial body, the Constitutional Court, which has assumed a very active role in legal creation because it adds contents to legislation and to the Constitution itself - a role that has been particularly intense in matters related with the protection of fundamental rights. And law created by the Constitutional Court takes a position which is higher than statutory law and immediately lower than the Constitution; therefore, judicial bodies must comply with the interpretation of the Constitution decided by the Constitutional Court, and also with the interpretation of the statutes done by the Constitutional Court, because the Constitutional Court decides how to interpret statutes so that they comply with the Constitution.

But I would like to show next that such a breakdown of legalistic model is not only due to the relevance of the decisions of the Constitutional Court but also of all other judicial bodies. This leads me to the second of the questions I mentioned at the beginning of this article: the doctrine of equality in the application of law.

\section{EQUALITY IN THE APPLICATION OF LAW}

From the very beginning of its activity, the Spanish Constitutional Court has underlined that equality before the law proclaimed by Article 14 of the Spanish Constitution must also be equality in the application of law. This is a question of a common sense: it is useless that law as such treats equally all the citizens if afterwards law is applied differently to some citizens from others. "There cannot be equality among citizens if there is no equality among the judgments concerning their behavior" ${ }^{10}$. Equality in the application of law means thus - as it was explained by one of the first decisions of the Spanish Constitutional Court which defined this doctrine - that "a same judicial body cannot arbitrarily modify its decisions on substantially similar cases, and, when the judicial body considers that it must

\footnotetext{
${ }^{10}$ A. Ollero, Igualdad en la aplicación de la ley y precedente judicial, Madrid 2005, p. 29.
} 
move away from its precedents, it has to provide a reasonable and sufficient justification" 11 . And, as right to equality is one of the fundamental rights declared by the Constitution which gives access to constitutional complaints (recurso de amparo), if an individual considers that equality in the application of law has been violated, he or she can denounce this injury before the Constitutional Court.

As it can be observed in the precedent text, four conditions must concur to appreciate a violation of equality in the application of law:

1. The precedent must be of the same judicial body.

2. Both cases must be substantially similar. This requires an estimation of the similarity between the cases, which can be difficult, to determine if it can be considered a substantial similarity. In any case, it is important to remark that equality has to be respected in the application of law, not in illegality: equality principle is not violated when a statute is applied that in a precedent case should have been applied and was not.

3 . The decision has been modified, either with respect to a temporally immediate precedent or to a consolidated trend in case-law.

4. The change of opinion has not been justified.

In short, we find that the binding force of precedents, that was totally alien to the Spanish legal system, as well as to other continental legal systems, has been introduced by an indirect way. Precedents have entered into the Spanish legal system as a result of the proclamation of the constitutional principle of equality, which of course must also be respected by judicial bodies, and which hinders judicial bodies to solve a case in a different way to a preceding one. In practice this means that, while in the past to invoke precedents as arguments in favor of the position defended by each of the parties in the process was completely irrelevant in Spain, today it becomes extraordinarily relevant, to the extent that, if a party can demonstrate consistently that a judicial body has moved away from a precedent without offering a reasonable justification, its decision can be revoked, even by the Constitutional Court through the procedure of constitutional complaint.

But this can only be applied to so-called self-precedent, which has been defined as "the one stemming from prior decisions made by the very same judge or court dealing with today's case" 12 . The Spanish Constitutional Court does not consider, on the contrary, that the principle of equality has been violated if the precedent ignored derives from a different judicial body, mainly because there is another way to assure the uniformity of application of law among different judicial bodies and organs: the hierarchical structure of the Judiciary, which allows decisions of lower

11 Decision 49/1982 (July 14), Legal Fundament No. 2.

12 M. Gascón, Rationality and Self-Precedent: Brief Considerations concerning the Grounding and Implications of the Rule of Self-Precedent. www.academia.edu/27065816/Rationality_and_ Self-Precedent [access: 05.09.2017]. 
courts to be revised by higher courts. In fact, the different regulations of judicial procedures in Spain stipulate that a justification for appeal to a higher Court can be the contradiction among decisions of courts of the same hierarchical level ("horizontal precedent"). And, of course, if a lower court takes a decision dissenting from the criteria established by the higher court, there is a great chance that its decision will be revoked if it is appealed, and the contradiction with the jurisprudence of the higher court ("vertical precedent") is also a justification for appeal ${ }^{13}$. That means, in short, that the binding force of both vertical precedents and self-precedents is recognized, whereas appeal to a higher court - that will then establish a vertical precedent - is the way to solve the problem of contradiction among courts of the same hierarchical level.

Of course, I am not defending that binding force of precedents has the same strength in Spain as in systems of common law. There is still a difference, due to the weight of different legal traditions. In Spain, as well in other continental legal orders, the justification of legal decisions will normally try to be based on applicable statutory norms, while in the United States, e.g., the value of stare decisis principle allows to rely only on a precedent which is similar to the present case to ground the decision, and it is often argued that a Court must adhere to the precedent even if it disagrees with the legal rule established in $\mathrm{it}^{14}$. But I think this difference is not substantial, but rather a difference of emphasis. As it has been shown, also in Spain precedents have achieved a considerable importance; and also in systems of common law, a judge or a court that disagrees with the precedent will try to distinguish it from the present case or to find strong reasons to overrule it. It can, therefore, be concluded that civil law and common law systems have approached in a considerable way.

\section{CONCLUSIONS}

In the last decades, a radical transformation of Spanish legal system has taken place, approaching it to systems of common law. The main actor of this change has been Constitutional Court. Its active role in legal creation and the authority of its decisions have enriched Spanish law with a new legal source of outstanding importance, which is Constitutional Court case-law. Moreover, the doctrine of equality in the application of law, developed by the same Constitutional Court, has given binding force to self-precedents, and, by extension, to vertical precedents. In

${ }^{13}$ See, e.g., both justifications for appeal before the Supreme Court in Section 477, No. 3, of Spanish Civil Procedure Act.

${ }^{14}$ See, e.g., R. Kozel, Stare Decisis as Judicial Doctrine, "Washington and Lee Law Review" 2010, Vol. 67, pp. 411-466, and the bibliography included. 
short, one of the main dogmas of legalistic positivism - the identification between law and statutory legislation - has collapsed.

Strangely enough, legal theory and teaching seem not to be aware of this substantial transformation. In Spain, we continue to use a method for the study of law which is predominantly based on the teaching of legislation. And we still teach that our legal system is fundamentally different from Anglo-Saxon legal systems, and that statutes are the main legal source. I hope these pages have contributed to show that this theory does not comply any more with real legal practice.

\section{REFERENCES}

Aja E., González Beilfuss M., Conclusiones generales, [in:] Las tensiones entre el Tribunal Constitucional y el legislador en la Europa actual, Barcelona 1998.

Brewer-Carías A.R., Constitutional Courts as Positive Legislators, [in:] General Reports of the XVIII ${ }^{\text {th }}$ Congress of the International Academy of Comparative Law, eds. K. Brown, D. Snyder, Dordrecht 2012, DOI: https://doi.org/10.1007/978-94-007-2354-2_23.

Cerri A., Corso di Gustizia Costituzionale, Milan 2001.

Domingo T., ¿Conflictos entre derechos fundamentales? Un análisis desde las relaciones entre los derechos a la libre información y expresión y los derechos al honor y la intimidad, Madrid 2001.

Gascón M., Rationality and Self-Precedent: Brief Considerations concerning the Grounding and Implications of the Rule of Self-Precedent.www.academia.edu/27065816/Rationality_and_Self-Precedent [access: 05.09.2017].

Kelsen H., Judicial Review of Legislation: A Comparative Study of the Austrian and the American Constitution, "The Journal of Politics" 1942, Vol. 4, DOI: https://doi.org/10.2307/2125770.

Kozel R., Stare Decisis as Judicial Doctrine, "Washington and Lee Law Review” 2010, Vol. 67. Lagi S., Hans Kelsen and the Austrian Constitutional Court (1918-1929), "Co-herencia" 2012, Vol. 9. Ollero A., Igualdad en la aplicación de la ley y precedente judicial, Madrid 2005.

\section{STRESZCZENIE}

Celem niniejszego artykułu jest wskazanie, że prawo hiszpańskie jest paradygmatycznym przykładem podejścia pośredniego między stosowaniem prawa w sposób tradycyjny (czyli kontynentalny) a modelem anglosaskim. Do dwóch głównych czynników, które spowodowały głęboką transformację hiszpańskiego systemu prawnego, należą: stanowisko Sądu Konstytucyjnego i jego aktywna postawa w tworzeniu prawa, a także doktryna precyzyjnie opracowana przez ten sąd na podstawie zasady równości w stosowaniu prawa. Zmiany te ukazują, że wyraźne tradycyjne rozróżnienie pomiędzy prawem cywilnym a systemem common law nie ma już racji bytu.

Słowa kluczowe: hiszpański system prawny; systemy prawa stanowionego; prawo precedensu 